INSTITUTE OF FORESTRY • BELGRADE

INSTITUT ZA ŠUMARSTVO • BEOGRAD

SUSTAINABLE FORESTRY

COLLECTION 69-70, 2014
ODRŽIVO ŠUMARSTVO

ZBORNIK RADOVA 69-70, 2014

UDK $630 * 114.52+630 * 181.34=111$

Original scientific paper

\title{
CHEMICAL CHARACTERISTICS OF GYPSY MOTH LARVAE EXCREMENT AND THEIR POSSIBLE IMPACT ON SOIL PROPERTIES IN THE TOTAL DEFOLIATION PERIOD
}

\author{
Zoran MILETIĆ, Mara TABAKOVIĆ-TOŠIĆ, Snežana STAJIĆ, Zlatan \\ RADULOVIĆ, Saša EREMIJA, Marija MILOSAVLJEVIĆ, Ivana ŽIVANOVIĆl
}

\begin{abstract}
Chemical properties of gypsy moth larvae excrement were analysed with an objective to ascertain their possible impact on forest ecosystem nutrient cycling. The content of nutrition macro-elements in excrements was determined and compared to the content of nutrition macro-elements in oak leaves. The content of nitrogen mineral forms in excrements and group-fractional composition of humus were determined. It was established that during the total defoliation period there had been no loss of nutrient in the ecosystem. The properties of dropped and incorporated excrements are such that in the period of new leave formation after the total defoliation provide a sufficient amount of nutrients for forest trees.
\end{abstract}

Key terms: gypsy moth, excrements, plant nutrients, soil properties

\section{HEMIJSKE KARAKTERISTIKE EKSKREMENATA LARVI GUBARA I NJIHOV MOGUĆI UTICAJ NA SVOJSTVA ZEMLJIŠTA U VREME GOLOBRSTA}

Apstrakt: U cilju sagledavanja mogućeg uticaja golobrsta na kruženje hranljivih materija u šumskim ekosistemima analizirana su hemijska svojstva ekskremenata larvi gubara. Određen je sadržaj makroelemenata ishrane u ekskrementima $i$ upoređen sa sadržajem istih u hrastovom lišću. Određen je sadržaj mineralnih oblika azota u ekskrementima i grupno frakcioni sastav humusa. Konstatovano je da tokom golobrsta nema većeg gubitka hranljivih materija u ekosistemu. Svojstva ekskremenata palih $i$ inkorporiranih su takva da u vreme ponovnog formiranja lišća posle golobrsta obezbeđuju dovoljne količine hranljivih materija za šumsko drveće.

\footnotetext{
${ }^{1}$ Institute of Forestry, Belgrade

Translation: Dejan Arsenovski
} 
Ključne reči: Gubar, ekskrementi, biljni asimilativi, svojstva zemljišta

\section{INTRODUCTION}

In stable forest ecosystems, a nutrient cycling balance is sustained. Forest trees and other taller plants assimilate soil nutrients soluble mineral forms and convert them into organic forms. The highest concentration of all nutrients assimilated by plants from soil is in assimilation organs, which deciduous trees, at the end of each of vegetation period, discard. Together with litterfall, organicallybound plant nutrients are transported to the soil surface. The soil organic layer, composed mostly of litterfall, is subject to decomposition processes as a result of the activity of saprophytic microorganisms. By means of biochemical decomposition processes, organic compounds of nitrogen, phosphorus, potassium and other elements are decomposed, while plant nutrients appear in mineral and plant available forms. Excessively fast decomposition of organic matter and occurrence of plant nutrients in soluble form have a negative long-term impact on soil fertility and production potential, as the wash-off of soil nutrients occurs, resulting in their withdrawal from ecosystem cycling.

A part of decayed organic plant residue is not mineralised into the final decomposition products, but transformed into humus. Humus is more resistant to decomposition processes in comparison to a decayed organic residue. Its decomposition is protracted, which enables a gradual release of nutrients in smaller amounts and leaves sufficient time for their assimilation by plants.

Assimilation of soil nutrients by forest trees is most intensive in spring season, in the period of phenophase foliation and formation of leaf mass, followed by autumn season, in the phenophase winter bud-filling period. At the same time, the largest number and the most intensive activity of saprophytic microorganisms occur, while nutrient conversion from organic into a plant available form is most intensive. In winter and summer period, the organic matter mineralisation processes are slowed down or completely interrupted, on account of adverse humidity or heat conditions for saprophyte activity.

The nutrient cycling balance in forest ecosystems can be disturbed by overproliferation of insect defoliators, which consume assimilation organs and cause excrement inflow onto the soil surface. In case of total defoliation, an ecosystem balance is completely upset. A large amount of excrement reaches the soil surface. Over-proliferation of gypsy moth and total defoliation take place in summer period, when biochemical decomposition processes, which are the result of saprophyte activity, are protracted on account of intense desiccation. That means that release of nutrient from organic matter is low, while the need for nutrients is high, as trees are compelled to repeat the foliation phase and restore leaf mass.

The subject of this paper is the study of chemical characteristics of gypsy moth excrement with an objective to ascertain their possible impact on soil and the living part of ecosystem during total defoliation period. 


\section{WORK METHOD}

The collection of gypsy moth larvae excrement was conducted in laboratory conditions. The consumption material of cultivated caterpillars consisted of leaves of various oak species (sessile oak, downy oak, Hungarian oak and Turkey oak). The gathered material was analysed in air-dry condition, while the obtained values of studied analytes were re-calculated for the absolutely dry condition. The consumption material was analysed as a single homogenised sample of different oak species.

The excrement and consumption material were burnt at $550^{\circ} \mathrm{C}$, and the elements found in the ash were converted into chlorides. From the obtained solution, total elements were determined, namely:

- Calcium and magnesium complexometric

- Potassium flame-photometric

- Phosphorus colorimetric

The total nitrogen and carbon content was determined by the Anstteta's 1956 method, (Ponomareva, Plotnikova 1975), by means of wet combustion in the $\mathrm{CrO}_{3}$ solution (chromium VI oxide) in sulphuric acid. The carbon content was determined by titration using $0.2 \mathrm{~N}$ Mohr's salt solution, while nitrogen was determined by distillation of ammonia and titration using sulphuric acid.

The content of nitrogen mineral forms in gypsy moth excrements was determined by application of the Bramner's method (Džamić et al 1996), whereas the active acidity was determined potentiometrically. The group-fractional composition of excrements humus was determined by the Ponomareva's method (Škorić, Racz 1960).

\section{STUDY RESULTS}

Based on the performed analyses, it can be concluded that gypsy moth larvae excrements are characterised by a higher content of ash and lower content of organic matter in comparison to gypsy moth consumption material, which consist of different oak species. With respect to the studied macro-elements of plants nutrition, a higher content of potassium in gypsy moth excrements was identified in comparison to that in the consumption material, whereas the content of total phosphorus, calcium and magnesium was lower (Table 1).

Table 1. Characteristics of gypsy moth excrements and their consumption material

\begin{tabular}{|c|c|c|c|c|c|c|c|c|}
\hline & \multirow{3}{*}{$\begin{array}{c}\text { Ash } \\
\%\end{array}$} & \multirow{3}{*}{$\begin{array}{c}\text { Organic } \\
\text { Matter }\end{array}$} & \multicolumn{2}{|c|}{$\mathrm{pH}$} & \multirow{2}{*}{$\mathrm{Ca}$} & \multirow{2}{*}{$\mathrm{Mg}$} & \multirow{2}{*}{ K } & \multirow{2}{*}{$\mathrm{P}_{2} \mathrm{O}_{3}$} \\
\hline & & & \multirow{2}{*}{$\mathrm{H}_{2} \mathrm{O}$} & \multirow{2}{*}{$\mathrm{KCl}$} & & & & \\
\hline & & & & & $\%$ & $\%$ & $\%$ & $\%$ \\
\hline Excrements & 5.43 & 94.57 & 4.64 & & 0.70 & 0.43 & 1.23 & 0.20 \\
\hline Consumption material & 4.26 & 95.74 & - & & 0.72 & 0.61 & 1.07 & 0.28 \\
\hline
\end{tabular}


The total nitrogen content, as well as carbon content, in gypsy moth excrements is lower than in their consumption material, while the carbon / nitrogen proportion is broader (Table 2). The broader carbon / nitrogen proportion, according to many authors (Ohta, Kumada 1978, Deqiang et al 2008, Fabiánek 2009), should represent an indication of slower decomposition of organic matter and slower conversion of plant nutrients from organic into mineral and plant available forms. However, a considerably large portion of total nitrogen (Table 2) in analysed excrements already consists of its mineral forms, while in the oak leaves all nitrogen is in organic form. Among the mineral forms of nitrogen in gypsy moth excrements, the ammonia form absolutely dominates $(13.85 \%$ of the total nitrogen), whereas the nitrate form of nitrogen also constitutes a significant part $(4.24 \%)$ of the total nitrogen. In natural soils, the largest part of total nitrogen is in organic form, whereas its mineral forms available by plants account for only $1-2 \%$ of the total nitrogen (Popović 1989).

Table 2. Nitrogen content in gypsy moth excrements and in their consumption material

\begin{tabular}{|c|c|c|c|c|c|c|}
\hline & $\mathrm{C}$ & $\begin{array}{c}\text { Total } \\
\mathrm{N}\end{array}$ & $\mathrm{NH}_{4}-\mathrm{N}$ & $\mathrm{NO}_{3}-\mathrm{N}$ & Mineral & \multirow{2}{*}{$\mathrm{C} / \mathrm{N}$} \\
\cline { 3 - 7 } & $\mathrm{g} / \mathrm{kg}$ & $\mathrm{g} / \mathrm{kg}$ & $\mathrm{g} / \mathrm{kg}$ & $\mathrm{g} / \mathrm{kg}$ & $\mathrm{g} / \mathrm{kg}$ & \\
\hline \multirow{2}{*}{ Excrement } & \multirow{2}{*}{319.16} & 18.017 & 2.496 & 0.7683 & 3.264 & \multirow{2}{*}{17.715} \\
\cline { 3 - 7 } & & $100.00 \%$ & $13.85 \%$ & $4.26 \%$ & $18.12 \%$ & \\
\hline Consumption material & 334.40 & 24.449 & - & - & - & 13.677 \\
\hline
\end{tabular}

Mineral forms of nitrogen cannot remain in soil for a long time. For that reason, as a result of gypsy moth larvae activities, and particularly during the total defoliation period, a higher loss of nitrogen could be expected from the total nutrient cycling balance in the ecosystem. The nitrate form of available nitrogen is highly soluble and mobile, for which reason it is subject to a rapid wash-off from the soil solum (Savić, Jekić 1975). A favourable circumstance, which mitigates the wash-off caused loss of nitrate during the total defoliation period, is that descendent streams are not very common in that period of year, as there is not much precipitation. The ammonia form of nitrogen is also subject to a wash-off, but to a significantly lower extent, as $\mathrm{NH}_{4}$ ion is adsorbed into the adsorption complex. The loss of ammonia nitrogen also takes place by volatilisation. It is particularly intensive in neutral and alkaline pedochemical environments, where the adsorption complex is already satiated with other base cations (Savić, Jekić 1975). A particularly strong acid reaction of gypsy moth excrements (Table 1) by means of volatilisation prevents the loss of ammonia from excrements. That means that ammonia nitrogen is lost from excrements through a wash-off, i.e. that it first reaches a soil solution. Subsequent behaviour of ammonia nitrogen depends on soil properties.

In the group-fractional composition of humus of gypsy moth excrements (Table 3), fulvic acids absolutely dominate humic acids. Among isolated fulvic acid fractions, the most highly represented is fraction 1, which is not connected with the mineral component and therefore it easily becomes subject to biological 
degradation. A significantly less represented is fulvic acid fraction 2, which is connected with calcium and magnesium and which is more resistant to biological degradation. Its representation in the group-fractional composition of humus accounts for $14.44 \%$. Among isolated fulvic acids, aggressive 1a fraction is also significantly represented. The carbon of aggressive fraction of fulvic acids accounts for $10.97 \%$ of the total carbon. A high representation of fulvic acids aggressive fraction explains excrements' acid reaction.

Table 3. Group-fractional composition of humus of gypsy moth larvae excrements

\begin{tabular}{|c|c|c|c|c|c|c|c|c|c|c|}
\hline \multirow{2}{*}{$\begin{array}{c}\text { Total } \\
\text { C }\end{array}$} & \multicolumn{3}{|c|}{ Humic acids } & \multicolumn{4}{|c|}{ Fulvic acids } & \multirow{2}{*}{$\begin{array}{l}\sum \mathrm{Chk} \\
+\sum \mathrm{Cfk}\end{array}$} & \multirow{2}{*}{$\begin{array}{c}\text { Remain } \\
\text { der }\end{array}$} & \multirow{2}{*}{$\begin{array}{l}\mathrm{Chk} / \\
\mathrm{Cfk}\end{array}$} \\
\hline & 1 & 2 & $\sum \mathrm{C} \mathrm{hk}$ & $1 \mathrm{a}$ & 1 & 2 & $\sum \mathrm{C} \mathrm{fk}$ & & & \\
\hline$\%$ & $\%$ & $\%$ & $\%$ & $\%$ & $\%$ & $\%$ & $\%$ & $\%$ & $\%$ & \\
\hline 31.92 & 1.88 & 0.17 & 2.05 & 3.50 & 5.26 & 3.65 & 12.41 & 14.46 & 17.46 & \\
\hline 100.00 & 5.88 & 0.53 & 6.41 & 10.97 & 16.49 & 11.44 & 38.89 & 45.31 & 54.69 & 0.165 \\
\hline
\end{tabular}

The content of humic acids is exceptionally low. The carbon producing isolated humic acids accounts for only $6.41 \%$ of the total excrements carbon. The proportion of humic and fulvic acids is exceptionally narrow and amounts to 0.165. Free humic acids (fraction 1), which are not connected with the mineral component and easily become subject to biological degradation are far more represented in the excrements humus in comparison to the grey humic acids (fraction 2). The representation of grey humic acids, which are less susceptible to biological degradation, as they are connected with calcium and magnesium, is negligible.

More than $50 \%$ of the total excrements carbon is in the insoluble residue. In natural soils, insoluble residue consists of fractions 3 of humic and fulvic acids, connected with clay and other stable sesquioxides, as well as humins, humus coal and insoluble organic matter of non-specific nature, such as lignin and cellulose. It can be assumed that in the studied excrements this insoluble residue mostly consists of lignin and cellulose's carbon, i.e. the carbon of hard-digesting organic matters which build vascular and mechanical tissues of oak leaves.

\section{CONCLUSION}

Based on the performed studies, it can be concluded that chemical characteristics of gypsy moth larvae excrements significantly differ from the consumption material, i.e. oak leaves. That difference is not that much pronounced in the total content of nutrition macro-elements, as it is in forms of their occurrence. In oak leaves, as well as in litter-fall, nutrition macro-elements are found in insoluble organic forms, while in excrements, a large portion of them is in mineral and plant available form. Certain macro-elements, such as nitrogen and phosphorous are less represented in the excrements than in the leaves, as they are used by gypsy moth for building their own cells. However, it does not mean that this portion of macro-elements withdraws from the nutrient cycling within forest ecosystems, as it will appear again on the soil surface following the die-off of gypsy moth. 
Although the largest portion of nutrients in excrements is in mineral form, which means in soluble and mobile form, their significant losses from the soil should not be expected, as descending movements of water are not pronounced at the time of a year when gypsy moth is most active. A high amount of plantavailable forms of plant nutrients, which in the total defoliation period reach the soil, facilitates the restoration of leaf mass after the total defoliation period, particularly given that mineralisation of organic matter is protracted in this time of year.

\section{REFERENCES}

Deqiang Zhang, Dafeng Hui, Yiqi Luo, Guoyi Zhou (2008): Rates of litter decomposition in terrestrial ecosystems: global patterns and controlling factors. Journal of Plant Ecology 1(2): 85-93, doi: $10.1093 / \mathrm{jpe} / \mathrm{rtn} 002.3$.

Džamić, R., Stevanović, D., Jakovljević, M. 1996. Manual for agrichemistry. Faculty of Agriculture, Belgrade [in Serbian].

Fabiánek, T. Menšík L., Tomášková I., Kulhavý J. (2009): Effects of spruce, beech and mixed commercial stand on humus conditions of forest soils. Journal of Forest Science, 55(3): 119-126.

Ohta S., Kumada, K. (1978): Studies on the humus forms of forest soils. VI. Mineralisation of nitrogen in brown forest soils. Soils Sc. Plant Nutrition, 24(1): 41.

Popović, Ž. (1989): Agrochemistry. Faculty of Agriculture/Naučna knjiga. Belgrade [in Serbian].

Ponomarieva, V. V. and Plotnikova, T. A. (1975). Determination of the content and composition of organic matter in peat soils. Methods of determination of humus content and composition in the soils (mineral and peat). Dokuchaev Central Soil Science Museum, St. Petersburg. [in Russian].

Savić, B., Jekić, M. (1975): Agrochemistry for the Students of Agronomy. Svjetlost, Sarajevo [in Serbian].

Škorić, A., Racz, Z. (1966): Determination of the content of humus. Manual for soil testing, Book. 1, Yugoslav Society for the soil study [in Serbian]. 